\title{
Hotspots of benthic production
}

SIR - Topographical features that accumulate organic debris, such as submarine canyons, are common along many coasts and can support hotspots of secondary production. The floor of the La Jolla submarine canyon $\left(32^{\circ} 52^{\prime} \mathrm{N}, 117^{\circ} 15^{\prime} \mathrm{W}\right)$ is covered by a persistent mat of surfgrass and kelp detritus from a depth of $15 \mathrm{~m}$ to at least $300 \mathrm{~m}$. The detritus is inhabited by a dense assemblage of amphipod (Orchomene limodes, Aoroides spinosus) and leptostracan (Nebalia spp.) crustaceans which at times achieve densities of more than 3 million individuals and biomass exceeding $1 \mathrm{~kg}$ (dry weight) per square metre. In monthly samples collected from March 1992 to March 1993, leptostracan density averaged $6.9 \times 10^{5} \mathrm{~m}^{-2}(\mathrm{~s}$. d. $4.4 \times 10^{5}$ ) and amphipods $7.8 \times 10^{5} \mathrm{~m}^{-2}$ (s. d. $2.7 \times 10^{5}$ ). The combined maximum density of these animals was $3,240,000 \mathrm{~m}^{-2}$, an order of magnitude greater than any natural macrofaunal assemblage reported in the literature (see figure).

The leptostracans averaged $4.5 \mathrm{~mm}$ long, and their secondary production, as calculated by the cohort summation of losses method ${ }^{1}$, was $3,300 \mathrm{~g}$ dry weight $\mathrm{m}^{-2} \mathrm{yr}^{-1}$ (production/biomass ratio $=7.2$ ). This value is an underestimate because many of the largest size classes could not be assigned to a cohort and were omitted from the calculation. The mean dry biomass of the amphipod assemblage during the study was $168 \mathrm{~g} \mathrm{~m}^{-2}$ and, assuming a production/biomass ratio of 4.0, amphipod annual production is estimated as $672 \mathrm{~g}$ dry weight $\mathrm{m}^{-2} \mathrm{yr}^{-1}$ (average length of amphipods, $2.2 \mathrm{~mm}$ ). I found only two measurements of secondary production in the literature with values approaching those found in the

1. Crisp, D. J. in Methods for the Study of the Marine Benthos (eds Holme, N. A. \& Macintyre, A. D.) 284-372 (Blackwell, Oxford, 1984).

2. Highsmith, R. C. \& Coyle, K. O. Nature $344,862-864$ (1990).

3. Pimm, S. L. Food Webs (Chapman and Hall, London, 1982).

4. Grassle, J. F. \& Grassle, J. P. J. mar. Res. 32, 253-284 (1974).

5. Levin, L. Ecology 65, 1185-1200 (1984).

6. Highsmith, R. C. Ecology 63, 329-337 (1982)

7. Anger, K. Int. Rev. ges. Hydrobiol, 62, 245-254 (1977).

8. Dayton, P. K. \& Oliver, J. Science 197, 55-58 (1977)

9. Birklund, J. Ophelia 16, 187-203 (1977).

10. Oliver, J. S., Slattery, P. N., Silberstein, M. A. \& O'Connor, E. F. Can. J. Zool. 62, 41-49 (1984)

11. Baden, S. P. Neth. J. Sea Res. 27, 81-92 (1990).

12. MacGinitie, G. E. \& MacGinitie, N. Natural History of Marine Animals (McGraw-Hill, New York, 1968).

13. Avery, W. E. \& Hawkinson, C. Northwest Sci. 66 199-203 (1992)

14. Gardner, J. P. A. \& Thomas, M. L. H. Mar. Ecol. Prog. Ser. 39, 31-36 (1987). present study (both were for bivalves).

Although enormous, the secondary production in the La Jolla canyon is localized, in contrast with the ampeliscid amphipods of the northern Bering Sea, which have much lower productivity per unit area $\left(30-40 \mathrm{~g}\right.$ dry wt $\left.\mathrm{m}^{-2} \mathrm{yr}^{-1}\right)$; but that estimate applies to an area of $2.2 \times 10^{4}$ to $3.75 \times 10^{4} \mathrm{~km}^{2}$ (ref. 2), a scale that may be unsurpassed anywhere in the world. During this study more than

below their maximum reported depth, and probably use the habitat and its resident fauna at much greater depths in the canyon.

These results raise the question of the general importance of such localized food hotspots to fish populations. At first glance they would seem a modest contribution in relation to the overall shelf and slope habitat, but consideration of the oceanographic literature suggests that hotspots may be critical for many species. The extreme importance of high-density food patches to many species of pelagic animals is becoming increasingly clear. The fish and zooplankton that survive and reproduce have somehow been able to locate and exploit foodrich patches. The same is probably true for many species of benthic and demersal fish and invertebrates. Cold seep and hydrothermal vent communities occur on a much smaller scale and are temporally ephemeral, but they also support high biomass and presumably very high rates of production, enriching what would otherwise be a very foodpoor environment.

Productivity hotspots may, in aggregate, be an important energy supply for fish production along some coasts. Systems such as this provide an important mechanism to channel marine macrophyte production into higher trophic levels through a saprotrophic food

$2,000 \mathrm{~m}^{2}$ of the detritus habitat were quantitatively sampled, but the total area of the mat within the La Jolla submarine canyon system probably exceeds 100,000 $\mathrm{m}^{2}$. The dense assemblage of crustaceans and their fish predators have been observed as deep as $60 \mathrm{~m}$, the maximum depth examined.

The amphipods are generally distributed within the top $10-20 \mathrm{~cm}$ of the detritus-mat and the leptostracans are most abundant $5-25 \mathrm{~cm}$ into the detritus; however, gut-content analysis and laboratory investigations indicate that leptostracans are the preferred prey of the mat-associated fishes. Large numbers of both demersal and pelagic fishes are nearly always present over the mat, and those fish, even species that typically prey on plankton, mega-invertebrates, and other fish, generally have their guts filled with the detritusdwelling crustaceans. Fish are the tertiary predators in this system and functionally 'shunt' the detritus-based saprotrophic production into the classic biotrophic coastal food web (G. Polis and D. Strong, manuscript submitted). Most of the fishes common at $15 \mathrm{~m}$ are also abundant at $60 \mathrm{~m}$; several of these species were found web. If, as suggested by $\mathrm{Pimm}^{3}$, extensive omnivory is destabilizing, extremely high secondary production by omnivores may persist only in detritusbased food webs with large inputs of allochthonous production. This situation exists in the La Jolla canyon and is expected to occur in other submarine canyons near to populations of marine macrophytes.

\section{Eric W. Vetter}

Scripps Institution of Oceanography, University of California, San Diego,

La Jolla, California 92093-0201, USA

\section{Scientific Correspondence}

Scientific Correspondence is a relatively informal section of Nature in which matters of general scientific interest, not necessarily those arising from papers appearing in Nature, are published. Because there is space to print only a small proportion of the letters received, priority is usually given according to general interest and topicality, to contributions of fewer than 500 words, and to contributions using simple language. 